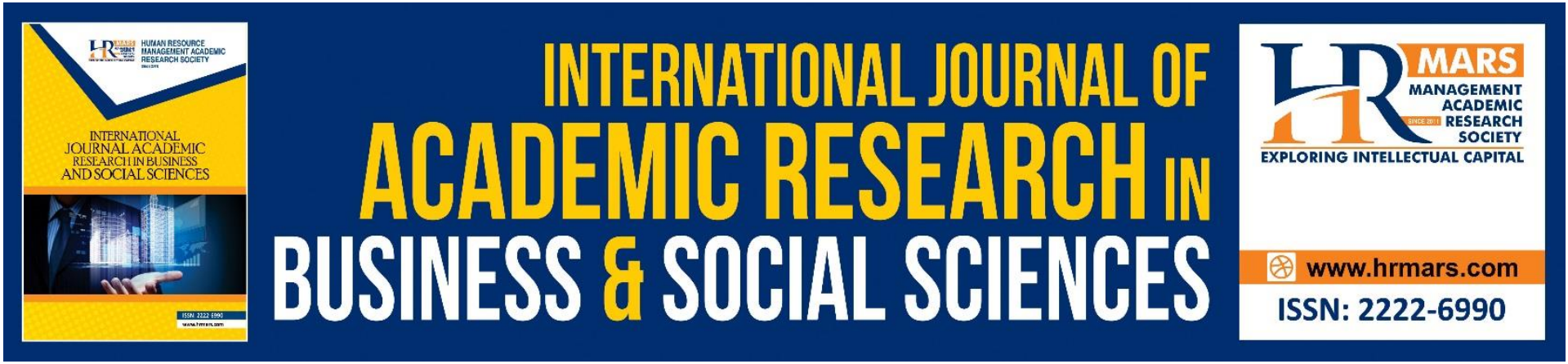

\title{
Bibliometric Analysis of Global Research Trends on Leadership Using Scopus Database
}

\author{
Mohd Faisal Mohd Hama, Batiah Mahadi
}

To Link this Article: http://dx.doi.org/10.6007/IJARBSS/v11-i10/11450

DOI:10.6007/IJARBSS/v11-i10/11450

Received: 05 August 2021, Revised: 29 August 2021, Accepted: 19 September 2021

Published Online: 17 October 2021

In-Text Citation: (Hama \& Mahadi, 2021)

To Cite this Article: Hama, M. F. M., \& Mahadi, B. (2021). Bibliometric Analysis of Global Research Trends on Leadership Using Scopus Database. International Journal of Academic Research in Business and Social Sciences, 11(10), 799-813.

Copyright: @ 2021 The Author(s)

Published by Human Resource Management Academic Research Society (www.hrmars.com)

This article is published under the Creative Commons Attribution (CC BY 4.0) license. Anyone may reproduce, distribute, translate and create derivative works of this article (for both commercial and non-commercial purposes), subject to full attribution to the original publication and authors. The full terms of this license may be seen at: http://creativecommons.org/licences/by/4.0/legalcode

Vol. 11, No. 10, 2021, Pg. $799-813$

Full Terms \& Conditions of access and use can be found at http://hrmars.com/index.php/pages/detail/publication-ethics 


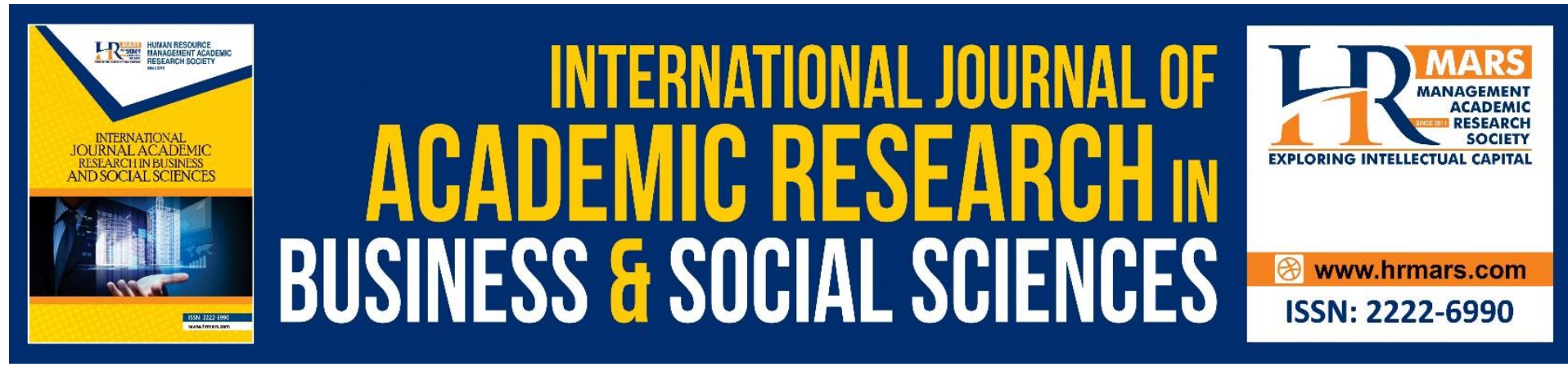

\title{
Bibliometric Analysis of Global Research Trends on Leadership Using Scopus Database
}

\author{
Mohd Faisal Mohd Hama ${ }^{1}$, Batiah Mahadi² \\ ${ }^{1}$ Department of Business Administration Azman Hashim International Business School \\ (AHIBS), Universiti Teknologi Malaysia, ${ }^{2}$ Department of Business Administration Azman \\ Hashim International Business School (AHIBS), Universiti Teknologi Malaysia. \\ Email: mfaisal72@live.utm.my, batiah.kl@utm.my
}

\begin{abstract}
The subject of leadership is endless. Inference is, as generation evolves; the leadership expectancy also changes to adapt with the changes in the environment it governs. For that reason, components of leadership are evolving with time. The search inquiries are coming from many approaches and the discoveries have offered range of solutions to address leadership challenges. Measuring and analysing scientific publications in leadership nevertheless is incomparable to the many publications have been published. This paper attempt to empirically evaluate global research trends on leadership based on publication output, prolific authorship, citations and affiliated countries using VOSviewer software. Additionally, to elevate co-occurrence keyword associated with leadership in literatures meant for insights into future work opportunity. 6,593 publications between year period of 1917 and 2019 retrieved from Scopus database. Through bibliometric analysis results, several observations have emerged. Firstly, the growth in publications number seen significant increase in last 20 years with anticipation the trends further to continue in the future. Secondly, the United States region presently dominating publication output in this area as well as leading in authorship citation compared to the other 98 countries. This suggests big research influence from this region on the present research. Thirdly, emotional intelligence, innovation, capability, knowledge management and management are some of the elevated keywords with high associations with leadership suggesting areas such as leadership capability as growing area. Lastly, under explore keyword association were noted such as digital leadership, leadership competencies, teams and social media which can be potential research themes for future studies.
\end{abstract}

Keywords: Leadership, Empirical Analysis, Trends, Scopus

\section{Introduction}

The subject of leadership nonetheless has been long discussed and researched for many years back and will still be studied for many years to come. The reason all is trying to achieve continuous understanding leadership roles and methods, on day-to-day events and it only will stop once generation evolution stops i.e., end of mankind. Inference is that as the generation evolves, the roles and methods of leadership changes to suit the environment it governs on 
to. For that reason, the components of leadership studies will continue to grow and evolve, to adapt with the changes of time and place. The search inquiries are coming from many approaches, from a perspective of individuals leaders (Dhar and Mishra, 2001; Yammarino and Bass, 1990; Kouzes and Posner, 2007; Yukl, 2008) and followers (Kouzes and Posner, 2010; Boyatzis, 1982; Farahnak et al., 2020) to what makes leadership at organizational and process level. The discoveries offer range of definitions and solutions in exercising leadership effectively (Tal and Gordon, 2016). It is a complex phenomenon and despite has been studied for many centuries, it still lacks consensus of what it is (Northouse, 2010).

Measuring and analysing scientific publications in leadership nevertheless is incomparable to the many publications have been published. Researchers believes a systematic review of articles publication through bibliometric analysis is now apposite as it may bring organization to the leadership body of knowledge (Vijayakumar et al., 2018; Marques et al., 2018; Batistic et al., 2017). Vijaya et. al (2018) presented Scopus indexed focussed on research trends in global leadership for period of 45 years of research published from 1971 to 2016. In similar specific topic approach, Marques et. al (2018) analysed the use of responsible leadership in management research from period of 2006 to 2016 using Web of Science (WoS) as source of data mining through Social Science Citation Index (SSCl) database. These searches despite their significant contribution on the specific knowledge of areas, it can be regarded as a subset of leadership and therefore does not quite represent full overview of leadership studies have been researched. Meanwhile, Tal \& Gordon (2016) conducted a bibliometric review on leadership articles in search of what new trends emerge in overall leadership studies. However, their search limited to Science and Social Science Citation Index Expanded (SCIE) and World Catalog (WC) database as source of data mining for a period of 49 years of publication from 1965 to 2014. Batistic et. al (2017) researched on similar path however using WoS as source of data mining from 1980 to 2013.

Whilst SCIE, SSCl, WoS and WC may provide high association in indexed journals, it is however indexing different journals (Khuzairi et al., 2018). In this paper is an attempt to use Scopus database searches up to recent years of 2019, to cover and expand searchers that may not be accessible on SCIE, SSCI, WoS and WC as searched by previous researchers e.g., Tal et. al (2016); Batistic et. al (2017). Researchers also argue Scopus being recognised as the largest abstract and citation database of peer-reviewed literatures may provide insights that another database did not cover (Vijayakumar et. al., 2018; Khuzairi et. al., 2018). In this paper, our objectives were as follows: 1) to analyse distribution trends of Leadership journal articles; ii) to show contributions of prolific authors, leading countries and the most productive publishers and research institutions; iii) to determine domination of countries based on major applications; and v) to provide insights into potential collaboration and future research directions.

\section{Theoretical Overview}

The interest on leadership has radiates from politics, psychology, education, development, management and to many others, portrays how significant and acknowledgement of society across all fields on the importance roles of leadership. According to Hassan, Asad and Hoshino (2016) the existing leadership labyrinth can be categorized under the realm of three main major scientific paradigms: Trait, Behaviour and Situational. Additionally, Callahan et. al., (2007) identified three orientations reference to leadership studies which are individualleader oriented, situational oriented and social dynamic oriented. Individual-leader oriented view on approach of understanding and recognizing individual traits, skills, competencies, 
approach and styles to lead, that exist within oneself. Secondly situational oriented focus on external predictors that affect and modified individuals' behaviours, styles and approach to lead. This includes situational, contingency and path-goal theory. Finally, social dynamics investigate interrelation and interactions between individuals namely leader follower dynamics which unveiling through transformational, leader-member exchange and team leadership concepts.

In early days, leadership perception was steered and associated with heroism influence by greatness of others such as Abraham Lincoln, Winston Churchill, Mahatma Gandhi and Mother Theresa. Traits celebrates and study prominent leaders in the world, extract the common traits impersonate across them and correlates with achievement accomplished. Behaviour and styles on the other hand accentuate how a perceived leader act and react on "how" and "why" with respect to their subordinates (Stodgill, 1974; Scheidlinger, 1994; Khan, 1956). Despite a substantive contribution, behaviour and styles doesn't address the impact of situational contingencies factor associate with leadership (Harrison, 2018) and performance outcome (Bryman, 1992; Yukl, 1994; Gill, 2011; Northouse, 2010) thus limited on the basis to theory building and orientation (House and Aditya 1997; Yukl 1999). Situational leadership stressing on the important of "situation" facet in predicting leadership performance and effectiveness. It encompassed on person exercising leadership roles adaptability to their situation at hand and to react accordingly. The fundamental of this theory argues that there is no single best style of leadership, encapsulate a concept that great leaders are those who well-adapt their methods to capture and attracts willingness of individuals or group they are attempted to lead and influence (Hersey and Blanchard, 1969; Blanchard, Zigarmi and Zigarmi, 2013).

Northouse (2018) citing Rost (1991) view leadership presently is no longer can be regard as personal traits and unique features of specific individual has and being replicated, but more of individual capability to exercise leadership roles to deliver what it needs to be delivered. According to Hassan et. al (2016), the proliferation on overlapping concepts and research results inconsistency on definitive link across leadership predictors and dividing clusters of perceptions amongst academicians and leadership gurus. Leadership complex in nature and involves multiple levels had made realization among researchers, it needs more inclusiveness and encapsulate as integrative constellations of attributes instead of isolation variables, to better predicts leader's effectiveness and outcome (Yukl and Van Fleet, 1992; Zaccaro et al., 2004; Yukl, 2006; Batistic et al., 2017; Dionne et. al., 2012).

The evolution of leadership research has seen therefore explain how big and depth leadership body of knowledge has grown, and how complex leadership concept can be. The area and topic of research expand with time to adapt with the changes in the environment it governs. Predicament is as generation evolves; the leadership expectancy also changes. The search inquiries are coming from many approaches and the discoveries have offered range of solutions to address leadership challenges with time. Through understanding leadership trends empirically based on publication output, prolific authorship, citations and affiliated countries, it serves as a cascade of the summary view on leadership interests and elevate insight into future work opportunity.

\section{Methods}

This paper adopts the use of bibliometric analysis, a statistical analysis of scholarly through publications quantifying physical and features articles published, or bibliographic or surrogates of (Batistic et. al., 2017; Broadus, 1987; de Solla Price, 1965). The analysis was 
conducted with the aid of VOSviewer software. VOSviewer is among the most prominent tools designed as a computer software and used to visualize the bibliometric data (Eck and Waltman, 2010; Eck and Waltman, 2014a; Eck and Waltman, 2014b; Eck, Waltman and Glanzel, 2017). Using this software; co-occurrences of author keywords, bibliographic coupling of the journals, bibliographic coupling of the countries, bibliographic coupling of the authors, bibliographic coupling of the publications, and bibliographic coupling of the institutions were analysed. Some recent leadership bibliometric analysis includes Vijayakumar et. al (2018) on "global leadership", Marques et. al (2018) on "responsible leadership", Vogel et. al (2020) on "leadership development" and Karakus (2017) on "ethical leadership". Scopus databased were used as in mining the data. This database is being recognised as the largest abstract and citation database of peer-reviewed literatures may provide insights that another database did not cover (Vijayakumar et. al., 2018; Khuzairi et. al., 2018) strengthen the justification of choosing this database. The data was retrieved and reviewed from within period of 19th February 2020 to 7th March 2020. Articles containing "leader*" on Abstract and Title were used as central theme of this study using query string of TITLE-ABS (leader*) which yields 286,219 documents.

Further refinement to search string were adopted to limit to Articles and Conference type paper to year search up to 2019. The query string used was: TITLE-ABS (leader*) AND ( LIMIT-TO ( DOCTYPE, "ar" ) OR LIMIT-TO (DOCTYPE, "cp")) AND ( EXCLUDE ( PUBYEAR , 2020 ) ) which resulted 218,980 documents. To ensure no review articles and no retracted documents were in the analysis, additional phrases were added to the search query strings to eliminate potentials review papers contained in the results such as AND NOT (TITLE ( "retracted" )) AND ( LIMIT-TO ( PUBSTAGE, "final" ) ) AND NOT ( TITLE ("retracted" OR bibliometric* OR potentiometric* OR scientometric* OR "annual report*" OR prospect* OR perspective* OR "critical factor*" OR "proposed factor*" OR "meta-analy*" OR review OR development OR prospect* OR trends OR perspective* OR highlight )). This has resulted 189,596 documents with undefined authors and language were eliminated in the process. Next in steps is the selection of journal these documents were published in. A noteworthy, to ensure the quality of searches and articles selected in the analysis, the considerations were only articles that satisfy and meet quality requirements of journal standard is selected. Harzing (2020) has published the Journal of Quality List (JQL) as to assist academics to analyse and search target papers of an appropriate standard. The JQL covers 12 globally accepted standard for journal's assessment of which as listed below:

1. European Journal of Information System 2007 Mingers and Harzing - EJIS2007

2. WU Wien Journal Rating May 2008 - WIE 2008

3. University of Queensland Adjusted ERA Ranking List - UQ 2011

4. Association of Professors of Business in German speaking countries - VHB 2015

5. Erasmus Research Institute of Management Journal Listing - EJL 2016

6. Danish Ministry Journal List August 2007 - Den 2017

7. Association of Business School Academic Journal Quality Guide March 2018 - ABS 2018

8. High Council for Evaluation of Research and Higher Education January 2018 - HCERES 2018

9. Australian Business Dean Council Journal Ranking List December 2019 - ABDC 2019

10. Centre National de la Recherche Scientifique June 2019 - CNRS 2019

11. Foundation National pour I'Enseignement de la Gestion des Enterprises June 2019 FNEGE 2019 
times more than period of pre year 2000. The rate of leadership articles published show significant growth start of 1990s (Table 1) and increases every 10 years. This view suggests the strong interest and relevancy on leadership topic and research. As such, it is expected that more leadership literatures will be published in coming years and future with a view as more research were published, there will be more gaps and limitation need to be address and therefore more research opportunity will be surfaced as researcher in the field research more and detail in nature. Worth to note, visual assessment on the Scopus search and outcomes, many of these articles are not readily accessible often cases require additional access and subscription to publisher. As Md Khuzairi et. al., (2018) infer, the citation number on articles will likely to be higher and more gaps could be addressed if their research were published as open access type.

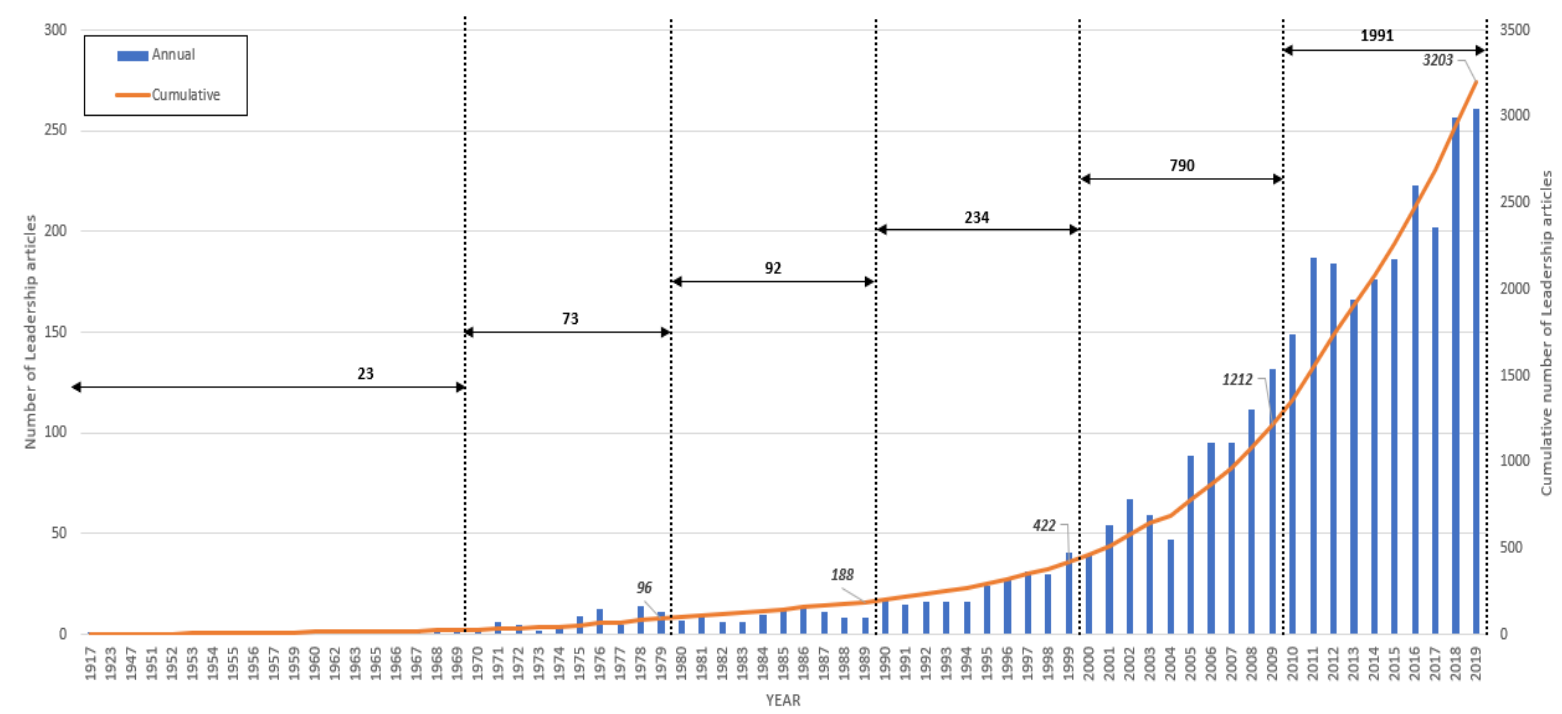

Fig.2: The annual and cumulative number of research articles on Leadership indexed in Scopus from 1917 to 2019.
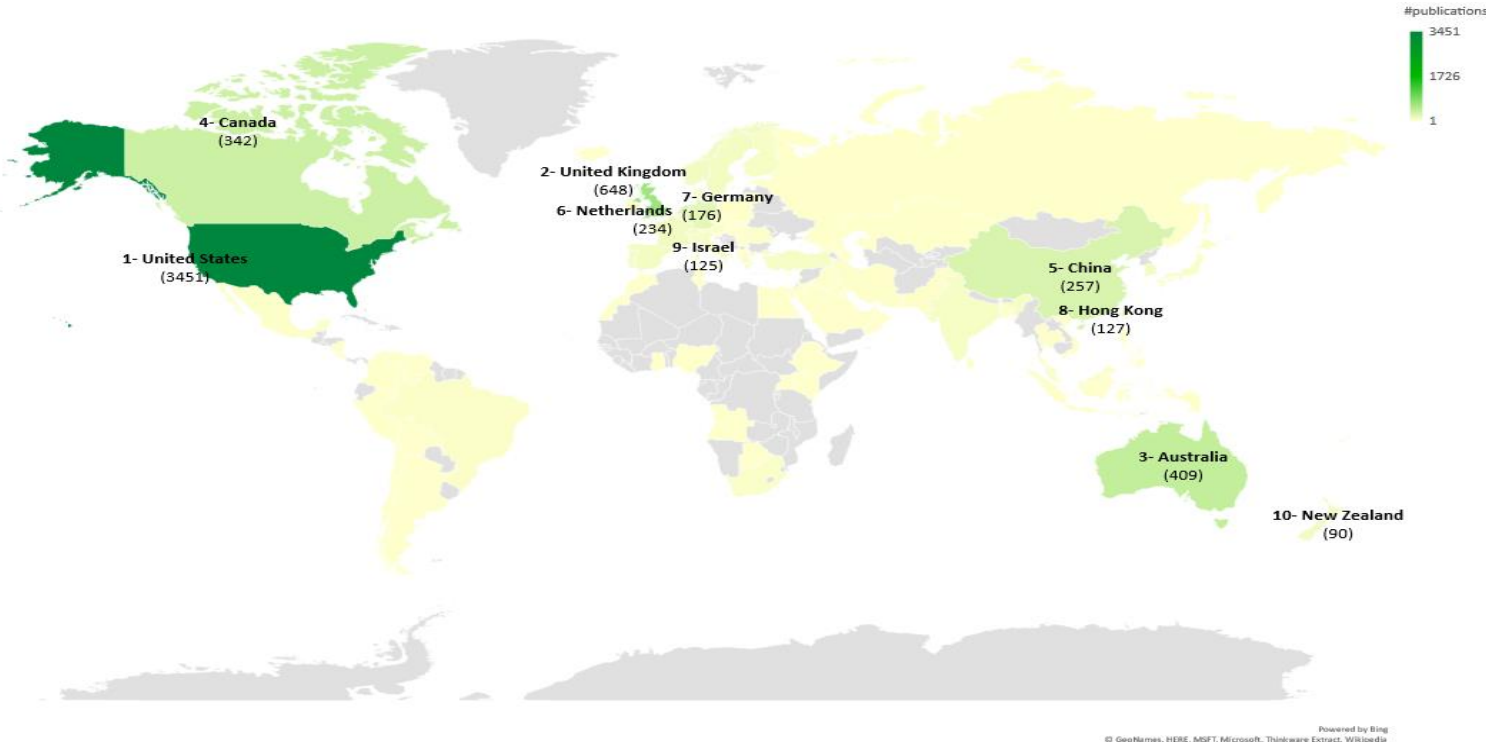

Fig. 3: Top 10 countries of research articles on empirical leadership research indexed in Scopus from 1971 to 2019. 
Fig. 3 shows top 10 most productive countries contributing to the growth in Leadership literatures. Empirical studies recorded at least 98 countries has published publication on Leadership with United States charting the highest percentage of contribution that is $43 \%$ of the publication and regards as key player in Leadership studies. This follows by United Kingdom (8\%), Australia (5\%), Canada (4\%), China (3\%), Netherland (3\%), Germany (2\%), Hong Kong (2\%), Israel (2\%), New Zealand (1\%) and Australia (1\%). Additionally, it is noted through Fig. 4, there are 40 countries out of 98 currently recorded more than 10 publications cumulative. Also noted that there significantly big gap in publication output published compared between United State and the rest of others, that count less than 1000 cumulative respectively for the rest of the countries compared to United State that is at least 3451 publications cumulative.

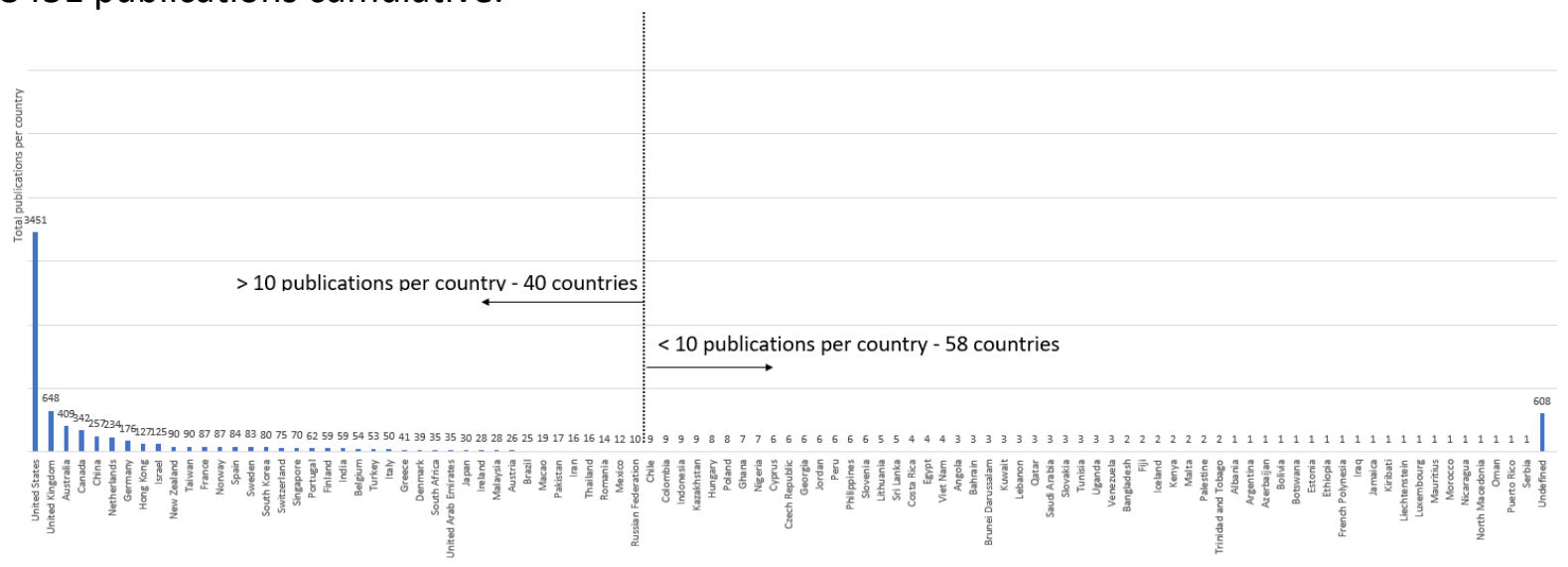

Fig. 4: Countries of research articles on empirical leadership research indexed in Scopus from 1971 to 2019.

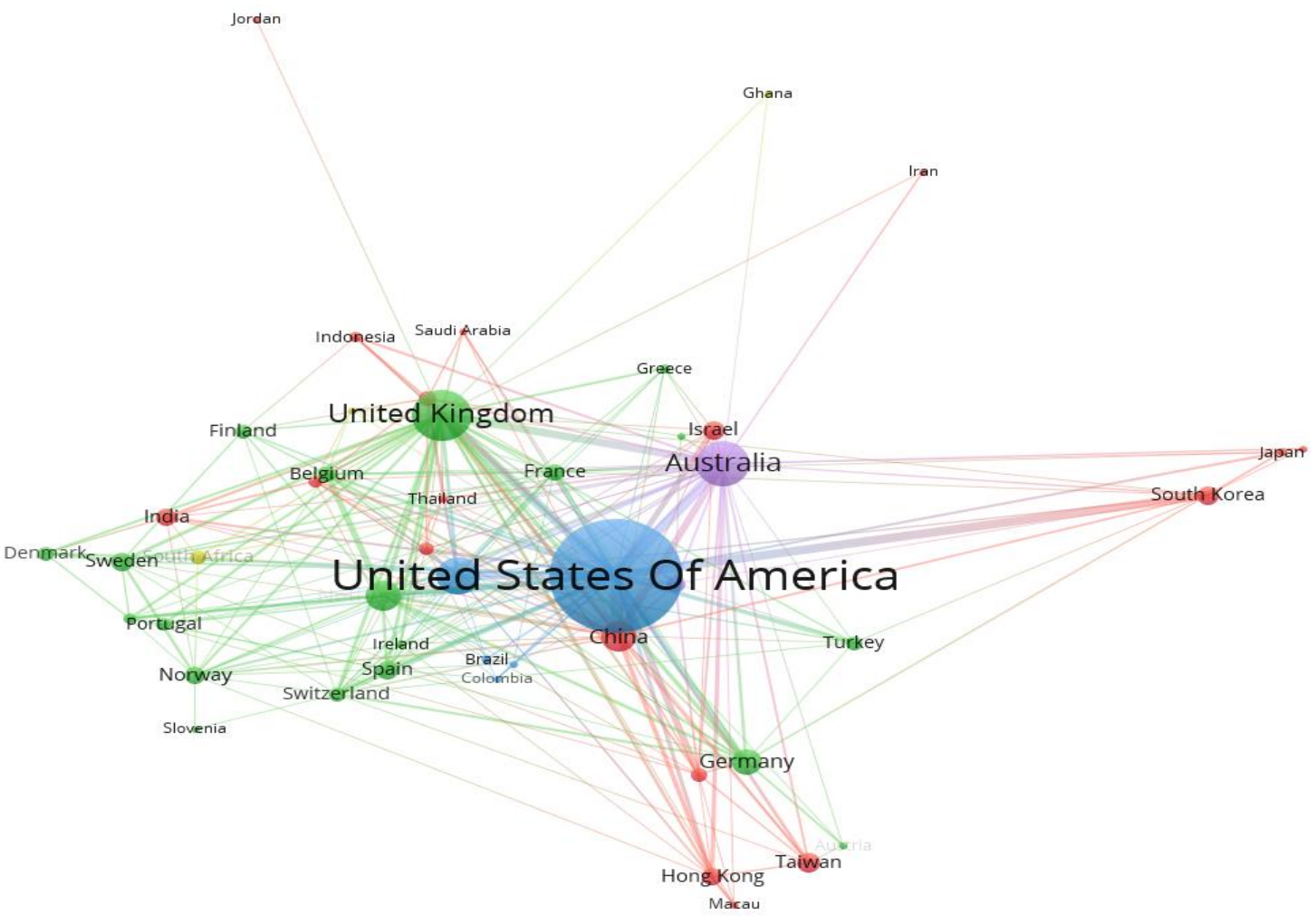

Fig. 5: Empirical leadership research indexed in Scopus from 1971 to 2019 VOSviewer bibliometric map based on co-authorships with network visualisation mode. 


\section{Preferred Journal and Leading Author}

Results showed on Fig. 6 and Table 2 are the top 10 journal and publications on Leadership research indexed in Scopus from 1971 to 2019. The result indicates Leadership Quarterly and Leadership and Organization Development Journal record the highest publication, regards as most productive journals with 291 and 290 total publications respectively. These two journals cover more than $10.6 \%$ of the total publication. These two journals were published by Elsevier and Emerald as two publishers with the highest number publications in Leadership studies. Emerald publisher leading the chart with about 458 publications that is $32 \%$ of its publications chart at top 10. Journal of Applied Psychology, Journal of Business Ethics, Journal of Management Development and Leadership journals also noted quite high number of Leadership publications with more that 100 total publication recorded ranging between $4 \%$ to $6 \%$ of total publication count follows behind Leadership Quarterly journal and Leadership and Organization Development journal.

\begin{tabular}{|c|c|c|c|c|c|c|c|c|c|}
\hline Journal & Total Pu & lication, & $\begin{array}{c}\text { Total } \\
\text { Citation, } \\
\mathrm{TC}\end{array}$ & $\begin{array}{l}\text { Cite Sore } \\
2018\end{array}$ & $\begin{array}{c}\text { Scopus } \\
\text { Coverage }\end{array}$ & The most cited articles (reference) & Author $(s)$ & Times cited & Publisher \\
\hline Leadership Quarterly & 291 & $10.63 \%$ & 21048 & 6.23 & $1990-2019$ & Ethics, character, and authentic transformational leadership behavior. & $\begin{array}{l}\text { Bass, B.M., Steidlmeier, P. } \\
\qquad(1999)\end{array}$ & 956 & Elsevier Inc. \\
\hline Leadership And Organization Development Journal & 290 & $10.60 \%$ & 3441 & 1.82 & $1980-2019$ & Emotional intelligence and leadership effectiveness. & $\begin{array}{l}\text { Kerr, R., Garvin, J, Heaton, N., } \\
\text { Bovle, E, (2006) }\end{array}$ & 150 & Emerald \\
\hline Journal of Applied Psychology & 160 & $5.85 \%$ & 12636 & 6.86 & $1917-2019$ & $\begin{array}{l}\text { Predicting unit performance by assessing transformational and transactional } \\
\text { leadership. }\end{array}$ & $\begin{array}{l}\text { Bess, B.M, Avolio, B.J, Jung, } \\
\text { D.I., Berson, Y. (2003) }\end{array}$ & 966 & APA \\
\hline Journal of Business Ethics & 153 & $5.59 \%$ & 4922 & 4.46 & $1982-2019$ & $\begin{array}{l}\text { Gender based barriers to senior management positions: Understanding the } \\
\text { scarcity offemale CEOs. }\end{array}$ & $\begin{array}{l}\text { Oakley, J.G. } \\
(2000)\end{array}$ & 331 & Springer Nature \\
\hline Joumal of Management Development & 124 & $4.53 \%$ & 2014 & 1.73 & $1982-2019$ & $\begin{array}{l}\text { The effect of organisational culture and leadership style on job satisfaction } \\
\text { and organisational commitment: A cross-national comparison. }\end{array}$ & $\begin{array}{l}\text { Lok, P., Crawford, J. } \\
\quad(2004)\end{array}$ & 276 & Emerald \\
\hline Leadership & 116 & $4.24 \%$ & 2077 & 1.68 & $2005-2019$ & $\begin{array}{l}\text { Discourses of Leadership: Gender, Identity and Contradiction in a UK Public } \\
\text { Sector Organization. }\end{array}$ & $\begin{array}{l}\text { Ford, } J . \\
(2006)\end{array}$ & 125 & SAGE \\
\hline Leadership Organization DevelopmentJournal & 80 & $2.92 \%$ & 3265 & 1.82 & $1980-2019$ & Transformational versus servant leadership: A difference in leader focus. & $\begin{array}{l}\text { Gregory Stone, A, Russell, R.F., } \\
\text { Patterson, K. (2004) }\end{array}$ & 276 & Emerald \\
\hline Joumal of Managerial Psychology & 76 & $2.78 \%$ & 2226 & 2.05 & $1986-2019$ & $\begin{array}{l}\text { Antecedents of organizational commitment and the mediating role of job } \\
\text { satisfaction. }\end{array}$ & $\begin{array}{l}\text { Lok, P., Crawford, }, \text {. } \\
\qquad(2001)\end{array}$ & 187 & Emerald \\
\hline International Journal Of Human Resource Management & 60 & $2.19 \%$ & 1502 & 271 & $1990-2019$ & $\begin{array}{l}\text { Leadership style, organizational culture and performance: Empirical evidence } \\
\text { from UK companies. }\end{array}$ & $\begin{array}{c}\text { Ogbonna, E, Harris, LC.C. } \\
\text { (2000) }\end{array}$ & 313 & Taylor \& Francis \\
\hline Joumal of Organizational Behavior & 60 & $2.19 \%$ & 4981 & 6.59 & $\begin{array}{l}1981-1982 \\
1984-2019\end{array}$ & $\begin{array}{l}\text { The empowering leadership questionnaire: The construction and validation } \\
\text { of a new scale for measuring leader behaviors. }\end{array}$ & $\begin{array}{l}\text { Arnold, l.A., Arad, S., Rhoades, } \\
\text { J.A., Drasgow, F. (2000) }\end{array}$ & 415 & Wiley-Blackwell \\
\hline
\end{tabular}

Table 2: Top 10 journal and publications on empirical leadership research indexed in Scopus from 1917 to 2019.

Interestingly, total publication does not correlate with number of citations. Whilst Leadership Quarterly journal still leading as overall with 21,048 total citation, Leadership and Organization Development Journal fall on the fourth place on total citation with 3441 total citations, after Journal of Applied Psychology with 12,363 of total citation, Journal of Business Ethics with 4922 of total citation. Accordingly, CiteScore 2018 report shows only 3 journals of the top 10 productive publication score higher than 5 . This is comparatively low since only covers $30 \%$ of the top 10. These journals are Journal of Applied Psychology with 6.86 followed by Journal of Organizational Behaviour with 6.59 and Leadership Quarterly with 6.23. Thus, this can deduce Leadership Quarterly and Journal of Applied Psychology are the two journals are most preferred, relatable and go to by researcher in Leadership studies through Elsevier and Emerald as publisher. 
INTERNATIONAL JOURNAL OF ACADEMIC RESEARCH IN BUSINESS AND SOCIAL SCIENCES Vol. 11, No. 10, 2021, E-ISSN: 2222-6990 @ 2021 HRMARS

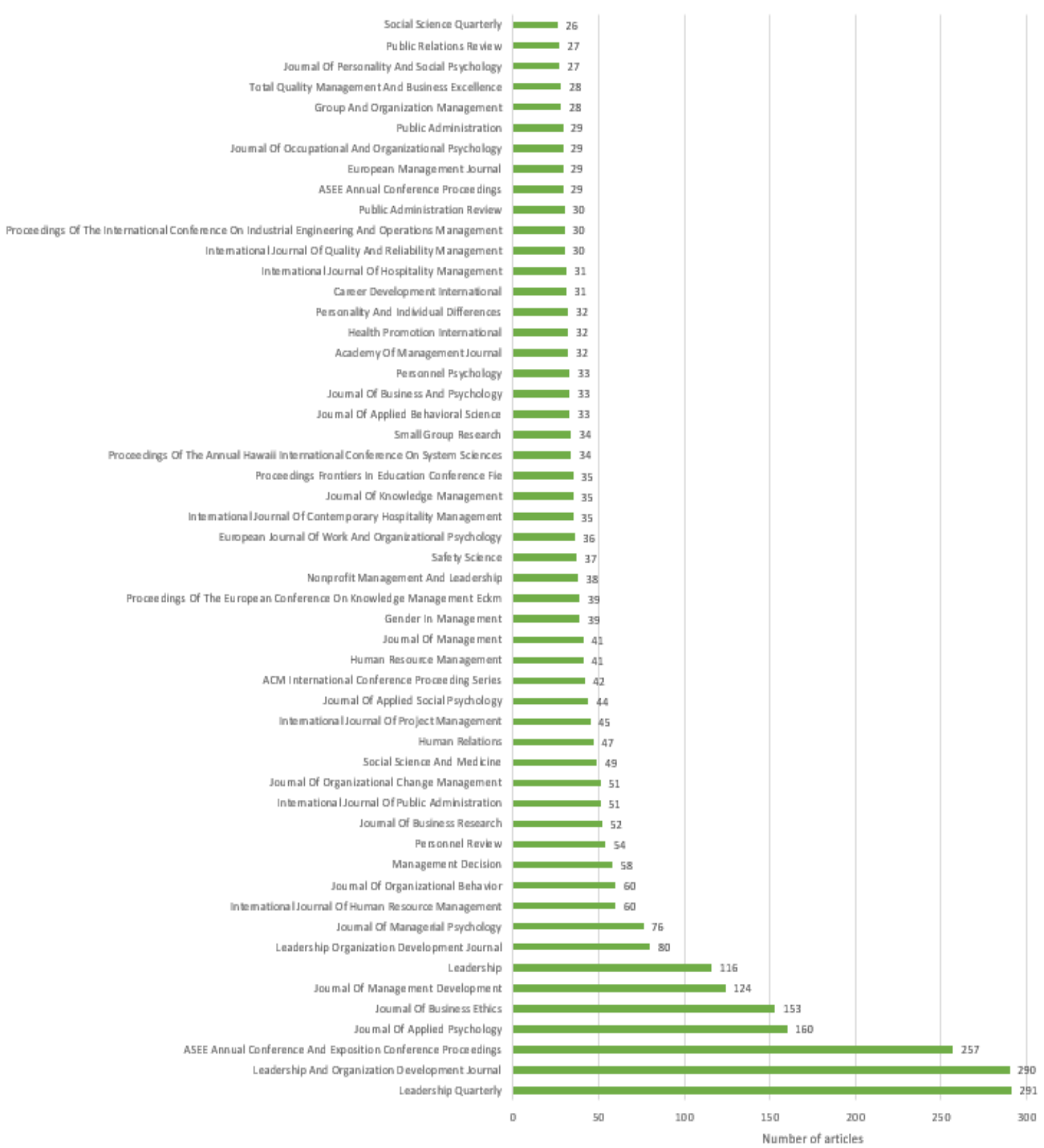

Fig. 6: Journal and publications on empirical leadership research indexed in Scopus from 1917 to 2019. 


\begin{tabular}{|c|c|c|c|c|c|c|c|}
\hline Author & Scopus author ID & $\begin{array}{l}\text { Year of 1st } \\
\text { publication }\end{array}$ & $\begin{array}{c}\text { Total } \\
\text { Publication, } \\
\text { TP }\end{array}$ & h-Index & $\begin{array}{l}\text { Total Citation, } \\
\text { TC }\end{array}$ & Current Affiliation & Country \\
\hline Avolio, Bruce J. & 7004253163 & 1987 a & 23 & 22 & 5169 & University of Washington & United States \\
\hline Sosik, John J. & 7003901310 & $1997 \mathrm{~b}$ & 19 & 18 & 1791 & Pennsylvania State University & United States \\
\hline Mumford, Michael D. & 7004956470 & 1993 a & 18 & 14 & 1074 & University of Oklahoma & United States \\
\hline Cremer, David De & 7006810104 & 2002 a & 14 & 13 & 612 & National University of Singapore & Singapore \\
\hline Newman, Alexander & 38862449600 & $2012 b$ & 14 & 10 & 397 & Deakin University & Australia \\
\hline Walumbwa, Fred Ochieng & 6507285069 & 2004 a & 14 & 13 & 1467 & Florida International University & United States \\
\hline Sarros, James C. & 6507805029 & $1997 \mathrm{c}$ & 12 & 9 & 313 & Monash University & Australia \\
\hline Waldman, David A. & 7006877282 & 1998 a & 10 & 10 & 741 & $\begin{array}{c}\text { Arizona State University Downtown } \\
\text { Phoenix Campus }\end{array}$ & United States \\
\hline Yammarino, Francis J. & 6603737478 & 1990 a & 10 & 10 & 889 & $\begin{array}{c}\text { Binghamton University State University } \\
\text { of New York }\end{array}$ & United States \\
\hline Bono, Joyce E. & 7005176946 & $2006 a$ & 9 & 7 & 1170 & Warrington College of Business & United States \\
\hline Miao, Qing & 57205253129 & $2012 \mathrm{a}$ & 9 & 8 & 333 & Zhejiang University & China \\
\hline Podsakoff, Philip M. & 6603818084 & $1992 \mathrm{~b}$ & 9 & 8 & 1367 & University of Florida & United States \\
\hline Zhu, Weichun & 7404231936 & 2005 a & 9 & 8 & 766 & Guangzhou University & China \\
\hline Bass, Bernard M. & 7102786103 & 1956 a & 8 & 7 & 3823 & $\begin{array}{c}\text { Binghamton University State University } \\
\text { of New York }\end{array}$ & United States \\
\hline Bligh, Michelle C. & 6602999766 & 2004 a & 8 & 6 & 337 & Claremont Graduate University & United States \\
\hline Lord, Robert G. & 7201583471 & 1980 a & 8 & 8 & 391 & University of Durham & United Kingdom \\
\hline Popper, Micha & 7003311071 & $1998 c$ & 8 & 8 & 902 & University of Haifa & Israel \\
\hline Schyns, Birgit & 14319168000 & 2008 a & 8 & 7 & 180 & NEOMA Business School & France \\
\hline Shamir, Boas & 6701445945 & 1992 a & 8 & 8 & 1480 & Hebrew University of Jerusalem & Israel \\
\hline Berson, Yair & 6602308658 & 2001 a & 7 & 7 & 1330 & Bar-Ilan University & Israel \\
\hline
\end{tabular}

Table 3: List of the 20 most prolific authors on empirical leadership research indexed in Scopus from 1917 to 2019.

Our search (Table 3) shows publication by Avolio, B. J. is the most prolific authors in Leadership studies as recorded in Scopus. Avolio, B. J. recorded with 23 total publications, 22 $\mathrm{h}$-index and total citation of his work leading the list recorded to 5169 counts since his first publication work in year 1987 affiliated with the University of Washington. This then followed by Sosik, J.J. with h-index of 18, 19 total publication and 1791 times citations since first publication in 1997 where he co-authored. Mumford, M.D. following the list as third most prolific authors with h-index of 14, 18 total publications and total citations of 1074 times. Noted on the empirical finding, event though Bass, B. M. has higher total citation counts compared to Sosic, J.J. and Mumford, M.D., with 3823 times of total citation, Bass, B.M. rank 14th of the list as most prolific author in leadership studies. Possible reason contribution to this is, looking at his first publications year, Bass, B.M. published much earlier compared to his peers in leadership studies. His research findings are likely most relatable with other researcher interest who might share his thought of process which can be seen on Table 4 . Similarly, to Avolio, B.J with the highest count of citation times but with more publication published compared to just 8 publications since 1956 for Bass, B.M for Leadership. Additionally, consistent with Fig. 2 and Fig. 3 above, most of the recorded prolific authors affiliated to the top 10 country with the most Leadership publications. 10 out top 20 most prolific authors affiliated to United States, followed by 3 authors with Israel, 2 author with Australia and China respectively, and 1 author affiliated with Singapore, United Kingdom and France each. Publication record of this number ranged between year 1956 to 2008 with 15 authors had roles as first author, 3 authors had roles as co-author and 2 authors as the last author. 


\begin{tabular}{|c|c|c|c|c|}
\hline Authors & Title & Year & Source title & Cited by \\
\hline Avolio B.J., Bass B.M., Jung D.I. & $\begin{array}{l}\text { Re-examining the components of transformational and transactional leadership using the } \\
\text { multifactor leadership questionnaire }\end{array}$ & 1999 & $\begin{array}{l}\text { Journal of Occupational and } \\
\text { Organizational Psychology }\end{array}$ & 1135 \\
\hline Bass B.M., Avolio B.J., Jung D.I., Berson Y. & Predicting unit performance by assessing transformational and transactional leadership & 2003 & Journal of Applied Psychology & 984 \\
\hline Bass B.M., Steidlmeier P. & Ethics, character, and authentic transformational leadership behavior & 1999 & Leadership Quarterly & 969 \\
\hline Zhang X., Bartol K.M. & $\begin{array}{l}\text { Linking empowering leadership and employee creativity: the influence of psychological } \\
\text { empowerment, intrinsic motivation, and creative process engagement }\end{array}$ & 2010 & Academy of Management Journal & 957 \\
\hline Podsakoff P.M., MacKenzie S.B., Bommer W.H. & $\begin{array}{l}\text { Transformational leader behaviors and substitutes for leadership as determinants of } \\
\text { employee satisfaction, commitment, trust, and organizational citize }\end{array}$ & 1996 & Journal of Management & 802 \\
\hline Fry L.W. & Toward a theory of spiritual leadership & 2003 & Leadership Quarterly & 691 \\
\hline Srivastava A., Bartol K.M., Locke E.A. & $\begin{array}{l}\text { Empowering leadership in management teams: Effects on knowledge sharing, efficacy, and } \\
\text { performance }\end{array}$ & 2006 & Academy of Management Journal & 674 \\
\hline Gong Y., Huang J.-C., Farh J.-L. & $\begin{array}{l}\text { Employee learning orientation, transformational leadership, and employee creativity: The } \\
\text { mediating role of employee creative self-efficacy }\end{array}$ & 2009 & Academy of Management Journal & 672 \\
\hline Carson J.B., Tesluk P.E, Marrone J.A. & Shared leadership in teams: An investigation of antecedent conditions and performance & 2007 & Academy of Management Journal & 631 \\
\hline Jung D.I., Chow C., Wu A. & $\begin{array}{l}\text { The role of transformational leadership in enhancing organizational innovation: } \\
\text { Hypotheses and some preliminary findings }\end{array}$ & 2003 & Leadership Quarterly & 629 \\
\hline Scandura T.A., Graen G.B. & $\begin{array}{l}\text { Moderating effects of initial leader-member exchange status on the effects of a leadership } \\
\text { intervention }\end{array}$ & 1984 & Journal of Applied Psychology & 616 \\
\hline Bycio P., Hackett R.D., Allen J.S. & $\begin{array}{l}\text { Further Assessments of Bass's (1985) Conceptualization of Transactional and } \\
\text { Transformational Leadership }\end{array}$ & 1995 & Journal of Applied Psychology & 549 \\
\hline Antonakis J., Avolio B.J., Sivasubramaniam N. & $\begin{array}{l}\text { Context and leadership: An examination of the nine-factor full-range leadership theory } \\
\text { using the Multifactor Leadership Questionnaire }\end{array}$ & 2003 & Leadership Quarterly & 538 \\
\hline Kirkpatrick S.A., Locke E.A. & $\begin{array}{l}\text { Direct and indirect effects of three core charismatic leadership components on } \\
\text { performance and attitudes }\end{array}$ & 1996 & Journal of Applied Psychology & 518 \\
\hline Treviño L.K., Brown M., Hartman L.P. & $\begin{array}{l}\text { A qualitative investigation of perceived executive ethical leadership: Perceptions from } \\
\text { inside and outside the executive suite }\end{array}$ & 2003 & Human Relations & 492 \\
\hline Ilies R., Morgeson F.P., Nahrgang J.D. & Authentic leadership and eudaemonic well-being: Understanding leader-follower & 2005 & Leadership Quarterly & 437 \\
\hline Bono J.E., llies $\mathrm{R}$. & Charisma, positive emotions and mood contagion & 2006 & Leadership Quarterly & 433 \\
\hline id S., Rhoades J.A., D & $\begin{array}{l}\text { The empowering leadership questionnaire: The construction and validation of a new scale } \\
\text { for measuring leader behaviors }\end{array}$ & 2000 & rational Behavior & 426 \\
\hline Aryee S., Sun L.-Y., Chen Z.X., Debrah Y.A. & Antecedents and outcomes of abusive supervision: Test of a trickle-down model & 2007 & Journal of Applied Psychology & 414 \\
\hline Ahearne M., Mathieu J., Rapp A. & $\begin{array}{l}\text { To empower or not to empower your sales force? An empirical examination of the } \\
\text { influence of leadership empowerment behavior on customer satisfaction and performance }\end{array}$ & 2005 & Journal of Applied Psychology & 410 \\
\hline
\end{tabular}

Table 4: List of the 20 most cited articles on empirical leadership research indexed in Scopus from 1917 to 2019.

\section{Preferred Topic of Interest}
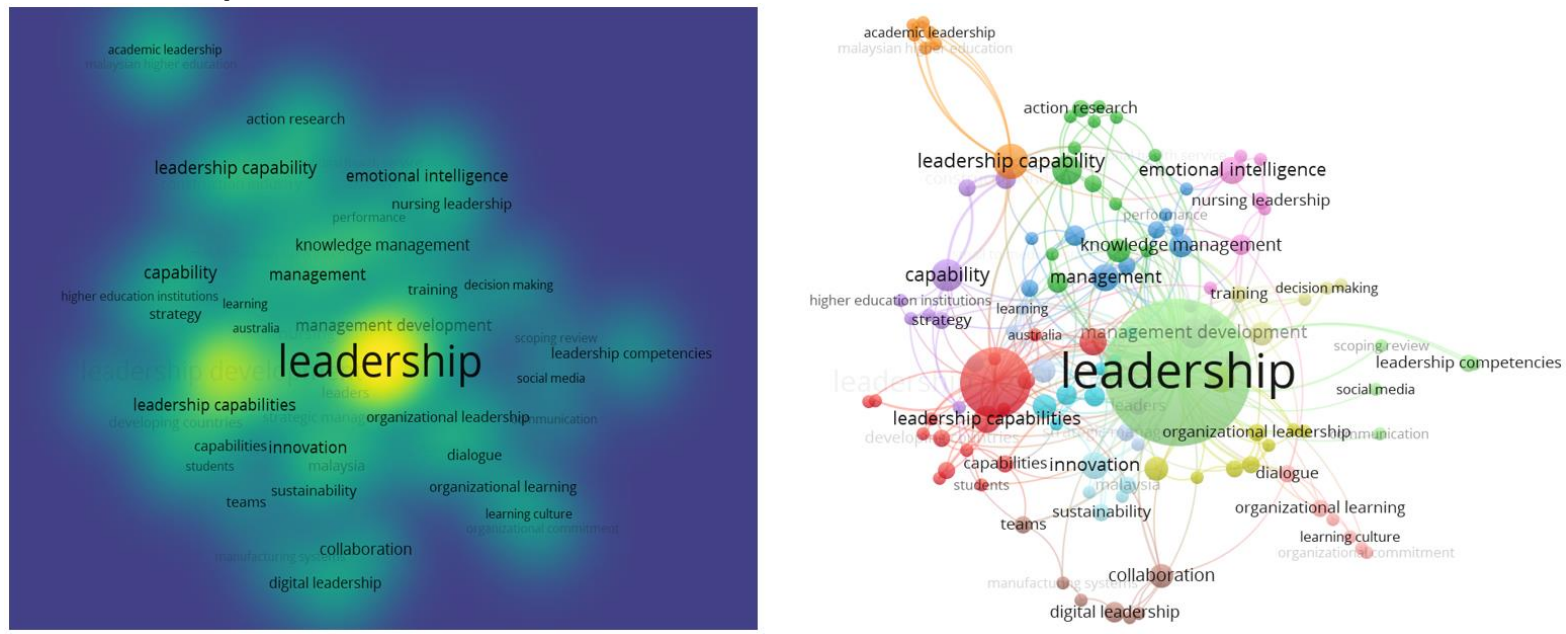

Fig. 7: Empirical leadership research indexed in Scopus from 2010 to 2019 viewed on VOSviewer bibliometric map based on keyword occurrence with density and network visualisation mode.

Fig. 7 portrayed outcome on occurrences of keyword associations with Leadership. It also noted that leadership keyword is the most terminology used in leadership studies with 2085 occurrences. It can be seen from the density visualisation that shows leadership capabilities has high association with leadership keywords. Additionally, there also high association of Leadership keywords with emotional intelligence, innovation, capability, knowledge management and management from the co-occurrence analysis. Furthermore, it also can be seen from Fig. 8 that recent year keywords associations with leadership are leaning towards leadership development, leadership capabilities, management development and knowledge management. It also noted that leadership research trend emerging its 
association with topic such as digital leadership, academic leadership, social media and team that could suggest as growing area for research exploration. The trends annotated regards as sensible from author point of view. As along post year 2010 to 2019, research seem realising impact of leadership then as researcher go along the timeline researchers started to discover what element of leadership and towards the last five years before start focussing on integrating leadership element and findings as an integrated concept and framework.

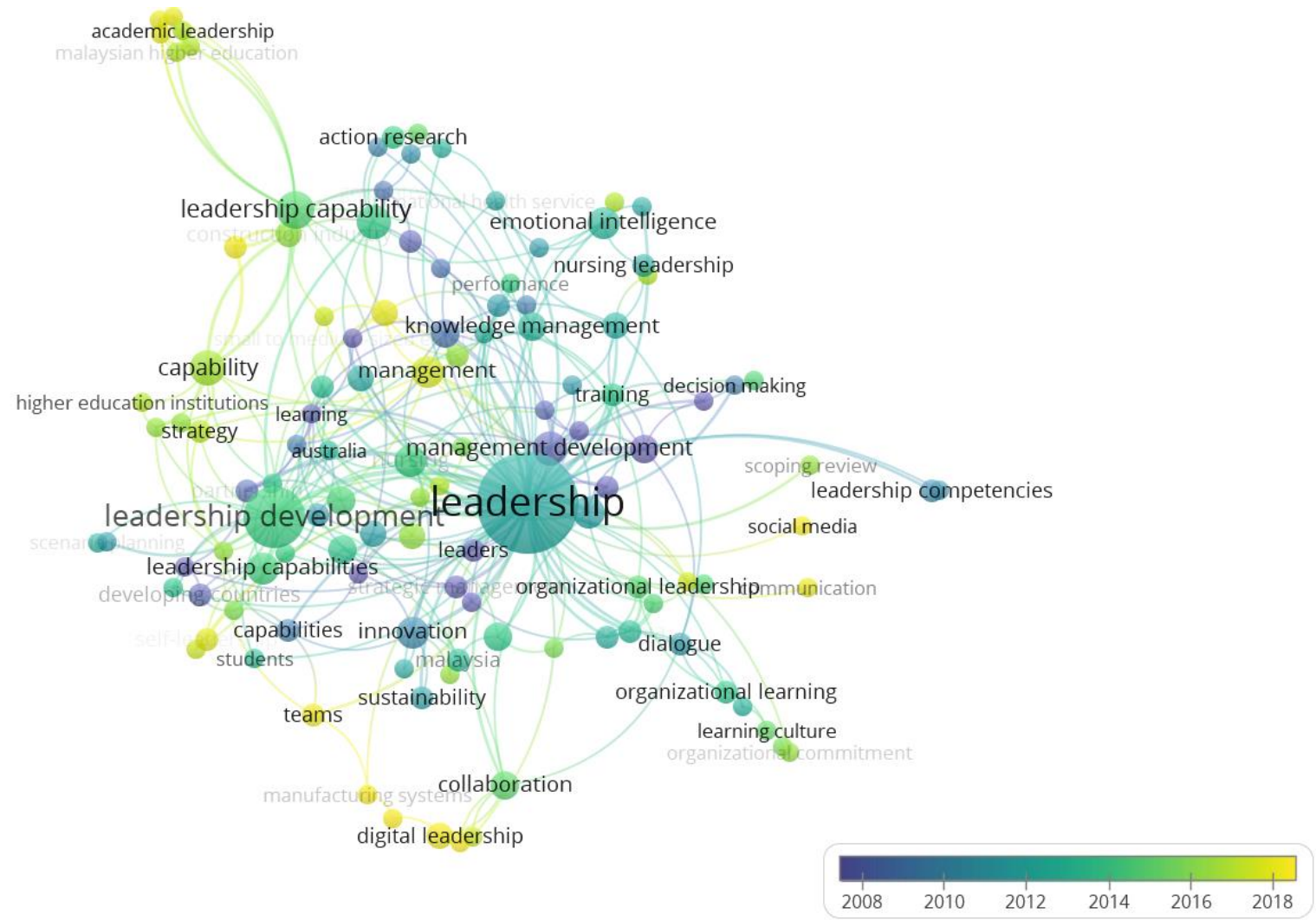

Fig. 8: Screenshot of VOSviewer bibliometric map based on occurrence in author keyword overlay by year from 2010 to 2019.

\section{Limitation of Study}

Restricting the search string to be (leader*) within the titles and abstracts likely comes with its own limitation. The search result may not cover every topic that may related to "leadership" as some research might be using different term and word. According to thesaurus there are at least 20 other words that synonyms for leadership. Additionally, the data populated through this study is up to year 2019 and data collection were collected on 13th March 2020. Since then, there might be more researched published on Leadership that may increase the sample size and strengthen keywords and associations. For future studies, it is recommended to compare similar parameter with other databases such as ScienceDirect and Web of Science. This may yield different links and strength depending on leadership articles that residing in these databases. Moreover, integrating dataset from all databases would be highly recommended as it has more dataset and likely has more co-occurrence of keywords within the leadership research context. 


\section{Conclusion}

Through this study overview for the last 102 years on Leadership research trends are portrayed based on 6593 publications retrieved from the Scopus database. The growth in number of publications since 1917 has increase and significantly rise rapidly for last 20 years and expected to further the trends in the future. United States presently dominating publication in this area of field and had massive influence on existing research where many citation citing authors of this cluster. The trends expected to continue however open opportunity for collaborations. It is noted that a number high concentrated association that stand out in Leadership research such as emotional intelligence, innovation, capability, knowledge management and management keywords and there are a number under explore such as digital leadership, leadership competencies, teams and social media which can be a potential for future studies.

\section{References}

Amin, M., Tatlah, I. A., \& Khan, A. M. (2013). Which leadership style to use? An investigation of conducive and non-conducive leadership style $(s)$ to faculty job satisfaction. International Research Journal of Arts \& Humanities (IRJAH), 41(41).

Batistič, S., Černe, M., \& Vogel, B. (2017). Just how multi-level is leadership research? A document co-citation analysis 1980-2013 on leadership constructs and outcomes. The Leadership Quarterly, 28(1), 86-103.

Boyatzis, R. E. (1982). The competent manager: A model for effective performance. John Wiley \& Sons.

Bryman, A. (1992), Charisma and Leadership in Organizations, Sage, London

Callahan, J. L., Whitener, J. K., \& Sandlin, J. A. (2007). The art of creating leaders: Popular culture artifacts as pathways for development. Advances in Developing Human Resources, 9(2), 146-165.

Dhar, U., \& Mishra, P. (2001). Leadership effectiveness. Journal of Management Research, $1(4), 254-266$.

Dionne, S. D., Chun, J. U., Hao, C., Serban, A., Yammarino, F. J., \& Spangler, W. D. (2012). Article quality and publication impact via levels of analysis incorporation: An illustration with transformational/charismatic leadership. The Leadership Quarterly, 23(6), 10121042.

Edition, F. N. (2020). JOURNAL QUALITY LIST.

Farahnak, L. R., Ehrhart, M. G., Torres, E. M., \& Aarons, G. A. (2020). The influence of transformational leadership and leader attitudes on subordinate attitudes and implementation success. Journal of Leadership \& Organizational Studies, 27(1), 98-111.

Gill, R. (2011). Theory and practice of leadership. Sage.

Harrison, N. (2018). Using the lens of 'possible selves' to explore access to higher education: A new conceptual model for practice, policy, and research. Social Sciences, 7(10), 209.

Hassan, H., Asad, S., \& Hoshino, Y. (2016). Determinants of leadership style in big five personality dimensions. universal journal of management, 4(4), 161-179.

Hersey, P., \& Blanchard, K. H. (1969). Life cycle theory of leadership. Training \& Development Journal.

House, R. J., \& Aditya, R. N. (1997). The social scientific study of leadership: Quo vadis?. Journal of management, 23(3), 409-473. 
Khudzari, J. M., Kurian, J., Tartakovsky, B., \& Raghavan, G. V. (2018). Bibliometric analysis of global research trends on microbial fuel cells using Scopus database. Biochemical engineering journal, 136, 51-60.

Kouzes, J. M., \& Posner, B. Z. (2007). The five practices of exemplary leadership. The JosseyBass reader on educational leadership, 63-74.

Kouzes, J. M., \& Posner, B. Z. (2010). The truth about leadership: The no-fads, heart-of-thematter facts you need to know. John Wiley \& Sons.

Lewin, K., Lippitt, R., \& White, R. K. (1939). Patterns of aggressive behavior in experimentally created "social climates". The Journal of social psychology, 10(2), 269-299.

Marques, T., Reis, N., \& Gomes, J. (2019). A bibliometric study on academic dishonesty research. Journal of Academic Ethics, 17(2), 169-191.

Northouse, P. G. (1999). Leadership: Theory and practice (p. xxiii). E-Content Generic Vendor. Northouse, P. G. (2010). Leadership: Theory and practice (5th ed.). Thousand Oaks: Sage

Portugal, E., \& Yukl, G. (1994). Perspectives on environmental leadership. The Leadership Quarterly, 5(3-4), 271-276.

Rost, J. C. (1991). Leadership for the twenty-first century. Greenwood Publishing Group.

Stogdill, R. M. (1974). Handbook of leadership: A survey of theory and research. Free Press.

Scheidlinger, S. (1994). The Lewin, Lippitt and White study of leadership and "social climates" revisited. International journal of group psychotherapy, 44(1), 123-127.

Tal, D., \& Gordon, A. (2016). Leadership of the present, current theories of multiple involvements: A bibliometric analysis. Scientometrics, 107(1), 259-269.

Vijayakumar, P. B., Morley, M. J., Heraty, N., Mendenhall, M. E., \& Osland, J. S. (2018). Leadership in the global context: Bibliometric and thematic patterns of an evolving field. In Advances in global leadership. Emerald Publishing Limited.

Yammarino, F. J., \& Bass, B. M. (1990). Long-term forecasting of transformational leadership and its effects among naval officers: Some preliminary findings. Leadership Library of America.

Yukl, G., \& Van Fleet, D. D. (1992). Theory and research on leadership in organizations.

Yukl, G. (1999). An evaluation of conceptual weaknesses in transformational and charismatic leadership theories. The leadership quarterly, 10(2), 285-305.

Yukl, G., \& Michel, J. W. (2006). Proactive influence tactics and leader member exchange. Power and influence in organizations, 87-103.

Yukl, G. (2008). How leaders influence organizational effectiveness. The leadership quarterly, 19(6), 708-722.

Zaccaro, S. J., Kemp, C., \& Bader, P. (2004). Leader traits and attributes. The nature of leadership, 101, 124.

Zigarmi, D., \& Roberts, T. P. (2017). A test of three basic assumptions of Situational Leadership ${ }^{\circledR}$ II Model and their implications for HRD practitioners. European Journal of Training and Development. 